Text of presentation (final)

Slide 1 - Title slide

\title{
Do extreme flood deposits in Wabash and Grand River valleys, Indiana and Michigan, relate to upstream subglacial floods?
}

\author{
C.F.M. Lewis and B.J. Todd
}

First, we recall that geothermal heat melted basal ice of the thick Laurentide Ice Sheet to produce a warm-based glacier in places and sometimes abundant meltwater. As well, supraglacial meltwater probably reached the ice bed (Zwally et al. 2002). The meltwater so produced was under thick ice and high pressure and could have attained high velocities which enabled it to entrain sand to even the coarsest clasts in till to become a turbulent highly erosive subglacial flow when released, possibly when a seal to the ground in the marginal ice zone was breached.

Also, we note that around the time of the ice maximum and during early deglaciation the ice sheet retreated in an oscillatory fashion, retreating 10 s to 100 s of kilometres, and then advancing again.

\section{Click - Slide 2}

In this talk, we advance the notion that escaping meltwater in a major subglacial flood, probably associated with ice streaming, eroded both the substrate and the overlying glacier leading to or contributing to thinning and breakup of that glacier and subsequent rapid recession of the ice margin. Such a retreat was commonly termed a substage, interstade or interstadial, now a recessional phase following the 1983 North American Stratigraphic Code, Johnson et al. (1997), and Karrow et al. (2000).

\section{Click}

Also, the corollary may be true. If an interstadial recession is recognized, then a contributing antecedent trigger for that ice recession may have been a major subglacial flooding and ice streaming event.

In this talk, all expressions of dates will be in thousands of calendar years before present as ka BP or just ka, except where mentioned otherwise. 
Two Interstadials or interstades in the southern Great Lakes region will be discussed - the Mackinaw Interstade about 16.0-15.9 ka and the Erie Interstade around 19.?-18.8 ka (Barnett 1992). Interstade was defined in 1984 and 1991 as 'a warmer substage of a glacial stage marked by a temporary retreat of the ice' (Bates and Jackson 1984), and as a 'phase of warmer climate within a glacial period, but of shorter duration than an interglacial' (Allaby and Allaby 1991). And in 2016, the Random House Dictionary described 'interstade' as 'a period of temporary retreat of ice during a glacial stage; a warming period'. In other words the ice recession of an interstade is thought to be related to a change to a warmer climate, although Karrow et al. (2000) referred to the interval simply as 'non-glacial'.

\section{Click - Slide 3: Greenland temperature history and Great Lakes Interstadials}

But we ask is climatic warming the only trigger for interstadial ice recession?

\section{Click}

The Greenland Ice Sheet atmospheric temperature history, shown here as temperature versus calendar age, is commonly considered an indicator of hemispheric climate, showing, for example, colder temperature (downward deviations) for the 8.2, and Younger Dryas cold events, and a warmer temperature (upward deviation) for the Bolling-Allerod warm period. We compare the temperature history over the Greenland Ice Sheet with the occurrences of interstadials in the Great Lakes region, shown in red font. We find the comparison unconvincing. Little temperature change in Greenland is shown for the Erie Interstade, and a cooling, sometimes called the Bolling-Allerod cool interval, occurs about the same time as the Mackinaw Interstade. Perhaps a local climate change occurred in the Great Lakes region that did not affect the Greenland Ice, or perhaps the ice recessions or interstadials had some other contributing cause. We pursue here the latter idea, that the ice recessions may be related to events other than climate change such as major subglacial meltwater floods.

\section{Click - Slide 4: Eastern Lake Ontario and northern New York State drumlins}

Here is what our studies in the eastern Great Lakes indicate, starting with this survey area in the deepest part of eastern Lake Ontario.

\section{Click}

A seismic line along the western side of the survey area reveals ridges shown in grey tone, interpreted as drumlins composed of diamict or subglacial till on bedrock. The drumlins range up to about $35 \mathrm{~m}$ high and are preserved beneath 
glaciolacustrine and Holocene lake sediments up to about $25 \mathrm{~m}$ thick in some places.

\section{Click}

Multibeam sonar bathymetry mapping reveals the drumlin shape and distribution, all oriented with SW trend. Note that narrow furrows are wrapped around the upstream noses of some drumlins.

\section{Click - Slide 5: Meltwater-eroded drumlins with upstream hairpin furrows}

These drumlins are interpreted, following Shaw (1994), to be remnants of the erosive work of horizontal vortices in a turbulent subglacial flow of meltwater, probably associated with streaming of the overlying ice.

\section{Click - Slide 6: SW movement follows S flow}

The SW movement of ice and subglacial meltwater is interpreted to have closely followed southerly flows of ice and subglacial meltwater as shown by route 1 in the image at left. The southerly meltwater flow deposited water-laid sediment in the bedrock basins of the Finger Lakes of northern New York State, according to Mullins et al. (1996). N-S oriented drumlins were also formed there, and on the north side of Lake Ontario. Termination of subglacial lake deposition in the Finger Lakes was dated around 16.8-16.4 ka based on paleomagnetic secular variation in the meltwater deposit and on a basal radiocarbon date of peat overlying meltwater sediment (Mullins et al. 1996) The switch to southwesterly flow, following the axial trend of the deep eastern Lake Ontario basin, is shown by route number 2 in the image at left. It is also indicated by trim lines which crosscut the N-S drumlins on each side of the Lake Ontario basin. These two flows were also recognized from onshore evidence by Shaw and Gilbert (1990). The switch from S to SW probably occurred as the south-flowing ice thinned and became more sensitive to the SW trend of the deep Lake Ontario basin. The onset of SW movement is inferred to have occurred around 16.4 to $16.2 \mathrm{ka}$ shortly after the basal peat date above and supported by an age estimate in the downstream Lake Erie basin, mentioned later.

\section{Click - Slide 7: Drumlins trend SW south of Lake Ontario}

The streaming southwesterly flows are traced by drumlin orientations south of Lake Ontario to the eastern Lake Erie basin.

\section{Click}

Seismic profiles and a borehole at the tip of Long Point reveal a lack of glacial till units in that basin. These units are interpreted to have been removed by the SW 
subglacial flows prior to $13{ }^{14} \mathrm{C}$ ka or 15.5 calendar or calibrated ka according to pollen-correlated horizons in the borehole.

\section{Click}

However, many units of subglacial deposition or tills dating to previous ice advances of the Port Bruce Phase 18.8-16.7 ka remain in the central basin of Lake Erie. The offshore Port Bruce units are traced to the northern Lake Erie shorebluff and onward to onshore recessional moraines.

The subglacial meltwater flows at approximately 16.4 to $16.2 \mathrm{ka}$ ended at the ice margin between Erie PA and the base of Long Point ON along the trend of the offshore Norfolk Moraine according to Dyke et al. (2003), Dyke (2004) and other glacial geologists, consistent with these observations. The subglacial flood removed most pre-existing glacial deposits from beneath the ice cover of the eastern Lake Erie basin, and likely eroded and weakened the overlying ice.

\section{Click - Slide 8: Lakes Maumee and Arkona and outflows to Gulf of Mexico}

Subglacial waters would have then flooded into proglacial Lake Maumee and the subsequent expanded Lake Arkona. The meltwater would have raised water levels and augmented the lake outflows down the Wabash River Valley in Indiana, and possibly down the Grand River Valley across Michigan.

\section{Click}

Both routes would have conveyed meltwater into the Mississippi drainage and the Gulf of Mexico where an extreme meltwater influx at the same time between about 16.4 to 16.1 ka has been identified by Aharon (2003) as 'MeltwaterFlood2' from negative spikes in the $\delta^{18} \mathrm{O}$ composition of foraminifera. The foraminifera are from marine sediment cores from the continental slope $S$ of Louisiana. And at the same time, the extreme flood incised the northern lower Mississippi River Valley, mainly in Missouri and Arkansas south of the Ohio River, to initiate deposition, prior to $16.1 \mathrm{ka}$, of the Kennett braided channel belt, a zone of braided sandy river deposits, shown in red on the slide, and dated by Rittenour et al. (2007) using optically stimulated luminescence methodology (OSL).

\section{Click - Slide 9: Maps of Mackinaw and Erie Interstades, and Nissouri Stade}

Subsequently, in just a century or so, the ice receded northward into the Lake Ontario and Lake Huron basins to establish the Mackinaw Interstade around 15.9-15.8 ka (Barnett 1992), and slightly earlier in the Lake Michigan basin (Monaghan and Hansel 1990). Thus ice recession in the Mackinaw Interstade might be explained, at least partly, by erosion, thinning and weakening of the preceding ice cover by a major subglacial meltwater flood around 16.4 to $16.2 \mathrm{ka}$. 


\section{Click}

This possible explanation of the Mackinaw Interstade raises the question whether an earlier ice recession, the Erie Interstade, which included Lake Leverett in the Lake Erie basin, at about 19.?-18.8 ka (Barnett 1992), was also induced by a meltwater flood.

\section{Click}

Ice advance in the preceding Nissouri Phase had extended southward beyond the Great Lakes basins. The Nissouri ice would have overlain the enigmatic 'glacial grooves' cut into Devonian limestone bedrock of the Finlay Arch comprising Kelley's and other islands in western Lake Erie.

\section{Click - Slide 10: Kelley's Island 'glacial grooves'}

The grooves were initially attributed to erosion by ice by Goldthwait (1979) and others.

\section{Click}

However, the long furrows are adorned with numerous small features which are commonly attributed to meltwater formation. The whole complex of linear furrows and adornments has since been recognized as having been formed in a major subglacial meltwater flow by Munro-Stasiuk et al. in 2005.

\section{Click}

Could this earlier flow be responsible for both the Kelley's Island grooves and subsequent ice recession in the Erie Interstade?

\section{Click - Slide 11: Mississippi Valley and Gulf of Mexico records}

Now, the Gulf of Mexico record is no older than 19.3 ka. But a possible hint of an earlier major meltwater flow is provided by onset of the Sikeston braid belt in the lower Mississippi River Valley. Segments of this belt are shown in yellow. The Sikeston braid belt would have been initiated by a major valley incising flood from the Laurentide Ice Sheet. Note in the inset diagram that both interstades were generally preceded by periods of high meltwater flow. The Sikeston braid belt began deposition by $19.7 \mathrm{ka}$ according to Rittenour et al. (2007). This age of 19.7 ka or one slightly older may be considered as a possible date of an earlier major westward flood through Erie basin and might account for both the 'glacial grooves' in western Lake Erie and the subsequent Erie Interstade.

\section{Click - Slide 12: Wabash and Grand River valleys, pictures of extreme flood deposits}


Outlet valleys of the Lake Erie basin and of Saginaw Bay in the southern Lake Huron basin are known to contain sedimentological evidence of extreme floods. The Grand River Valley across Michigan is reported by Kehew (1993) to have experienced one such flood at least. A flood deposit in the Grand River valley is illustrated at the top of the slide. The Wabash River Valley in Indiana draining the Lake Erie basin was reported in 1988 by Fraser and Bleuer to contain deposits of two such extreme floods. Deposits of one of these floods are shown by images at the bottom of the slide. However, ages of these floods have not been determined and published to our knowledge.

If the ages of the extreme floods that were conveyed by these valleys were known, we might be better able to interpret the extreme events which played a major role in forming or modifying the landscape beneath the southern Laurentide Ice Sheet. Some of the flood deposits likely contain sand-size sediment and might be dated by optically stimulated luminescence methodology, especially deposits of the younger flood about 16.4-16.2 ka which were distant from the ice margin and may have been exposed to sufficient light for OSL dating. Sandy beach deposits of Lake Leverett in the Erie Interstade, shown at right on the slide, might also be dated.

\section{Click}

We urge members of the dating community to consider applying their talents to determine the ages of extreme floods conveyed by the Wabash and Grand river valleys, and thus to advance possible linkages between upstream effects of subglacial floods in the Great Lakes region, and their counterpart effects downstream in the Mississippi River Valley and Gulf of Mexico.

\section{Acknowledgements}

We thank G.D.M. Cameron (Geological Survey of Canada, Dartmouth) for review of the abstract, and D.R. Sharpe (Geological Survey of Canada, Ottawa) and J. Shaw (University ofAlaberta, Edmonton) for helpful comments on the presentation.

\section{References for citations in text and slides}

Aharon P. 2003. Meltwater flooding events in the Gulf of Mexico revisited: implications for rapid climate changes during the last deglaciation.

Paleoceanography 18: 1079, 3-1-3-14.

Allaby A, and Allaby M. 1991. Oxford Dictionary of Earth Sciences. Oxford University Press, Oxford, England. 
American Commission on Stratigraphic Nomenclature (1983). Code of Stratigraphic Nomenclature. American Association of Petroleum Geologists Bulletin 67: 841-875.

Barnett PJ. 1992. Quaternary geology of Ontario. In Thurston PC, Williams HR, Sutcliffe RH, and Stott GM. (eds.) Geology of Ontario. Ontario Geological Survey, Special Volume 4, Part 2, Toronto, Ontario, pp. 1001-1088.

Bates RL, and Jackson JA. 1984. Dictionary of Geological Terms, $3^{\text {rd }}$ edition, The American Geological Institute, New York NY.

Dyke AS. 2004. An outline of North American deglaciation with emphasis on central and northern Canada. In Ehlers J, and Gibbard PL (eds.) Quaternary Glaciations - Extent and Chronology, Part II: North America. Developments in Quaternary Science 2b, Elsevier, Amsterdam.

Dyke AS, Moore A, and Robertson L. 2003. Deglaciation of North America. Geological Survey of Canada, Open File 1574.

Fraser GS, and Bleuer NK. 1988. Sedimentological consequences of two floods of extreme magnitude in the late Wisconsinan Wabash Valley. In Geological Society of America Special paper 229: 111-125.

Goldthwait RP, 1979. Giant grooves made by concentrated basal ice streams. Journal of Glaciology 23: 297-307.

Johnson WH, Hansel AK, Bettis III EA, Karrow PF, Larson GJ, Lowell, TV, and Schneider AF. 1997. Late Quaternary temporal and event classifications, Great Lakes region, North America. Quaternary Research 47: 1-12.

Karrow PF, Dreimanis A, and Barnett PJ. 2000. A proposed diachronic revision of late Quaternary time-stratigraphic classification in the eastern and northern Great Lakes area. Quaternary Research 54: 1-12.

Kehew AJ. 1993. Glacial-lake outburst erosion of the Grand Valley, Michigan, and impacts on glacial lakes in the Lake Michigan basin. Quaternary Research 39: $36-44$.

Lewis CFM, and Anderson TW. 1992. Stable isotope (O and C) and pollen trends in eastern Lake Erie, evidence for a locally-induced event of Younger Dryas age in the Great Lakes basin. Climate Dynamics 6: 241-250.

Lewis CFM, Cameron GDM, Barnett PJ, and Anderson TW. 1986.

Onshore-offshore correlation of Late Wisconsinan strata, central Lake Erie, and implications for regional geology (Abstract). Geological Association of Canada Program with Abstracts, v. 11. 
Lewis CFM, Moore Jr TC, Rea DK, Dettman DL, Smith AM, and Mayer LA. 1994. Lakes of the Huron basin: Their record of runoff from the Laurentide Ice Sheet. Quaternary Science Reviews 13: 891-922.

Licciardi JM, Teller JT, Clark PU. 1999. Freshwater routing by the Laurentian ice sheet during the last deglaciation. In Clark, PU, Webb RS, Keigwin LD. (eds.), Mechanisms of Global Climate Change at Millennial Time Scales. Geophysical Monograph, vol. 112, p. 394. American Geophysical Union, Washington DC, pp. 177-201.

Monaghan GW, and Hansel AK. 1990. Evidence for the intra-Glenwood (Mackinaw) low-water phase of glacial Lake Chicago. Canadian Journal of Earth Sciences 27: 1236-1241.

Mörner N-A, and Dreimanis A. 1973. The Erie Interstade. In Geological Society of America Memoir 136: 107-134.

Mullins HT, Hinchey EJ, Wellner RW, Stephens DB, Anderson Jr. WT, Dwyer TR, and Hine AC. 1996.Seismic stratigraphy of the Finger Lakes: A continental record of Heinrich event $\mathrm{H}-1$ and Laurentide Ice Sheet instability. In Mullins HT, and Eyles N (eds.) Subsurface Geologic Investigations of New York Finger Lakes, implications for Late Quaternary and Environmental Change. Geological Society of America Special Paper 311, Boulder CO.

Munro-Stasiuk MJ, Fisher TG, and Nitzsche CR. 2005. The origin of western Lake Erie grooves, Ohio: implications for reconstructing the subglacial hydrology of the Great Lakes sector of the Laurentide Ice Sheet. Quaternary Science Reviews 24: 2392-2409.

Random House Webster's Unabridged Dictionary. 2016.

Rittenour TM, Blum MD, and Goble RJ. 2007. Fluvial evolution of the lower Mississippi River valley during the last 100 k.y. glacial cycle: Response to glaciation and sea-level change. Geological Society of America Bulletin 119: 586-608.

Shaw, J. 1994. Hairpin erosional marks, horseshoe vortices and subglacial erosion. Sedimentary Geology 91: 269-283.

Shaw J, and Gilbert R. 1990. Evidence for large-scale subglacial meltwater flood events in southern Ontario and northern New York State. Geology 18: 11691172.

Zwally, HJ, Abdati W, Herring T, Larsen K, Saba J, and Seffen K. 2002. Surface melt induced acceleration of Greenland Ice-sheet flow. Science 297: 218-222. 